\title{
State Coordination of Higher Education and Academic Libraries
}

\author{
Vicki L. Gregory
}

This study consists of a historical descriptive exploration on the attention given over the past twenty years by state coordinating agencies of higher education to academic libraries in terms of (1) funding and funding formulas and (2) statewide library networks and other statewide cooperative programs. A mailed survey was conducted in fifteen states, representing all regions of the United States, and forty-five interviews were conducted in eight states. Several factors were identified that appear to be related to the perceived success in the interaction of the state coordinating agencies and their respective academic libraries, and a theory concerning that interaction is advanced.

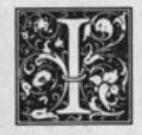

$\mathrm{n}$ the period following World War II, almost every state established an agency to coordinate centrally the planning and/or financing of state colleges and universities. Prior to 1950, less than a third of the states had such agencies; however, by 1983 all but three states possessed some kind of coordinating agency. Today, these agencies are of three main types: advisory coordinating boards, regulatory coordinating boards, and consolidated governing boards. ${ }^{1}$ These different types of boards can be defined as follows.

An advisory coordinating board is defined as a "state-mandated agency [by statute, executive order, or constitutional provision] which does not supersede institutional or segmental governing boards and gives advice and recommendations on higher education to institutions and state agencies."

A regulatory coordinating board is defined as a "state-mandated agency which does not supersede institutional or segmental governing boards and has final approval powers in at least certain key policy areas."

A consolidated governing board is defined as "one single board which governs and coordinates all public higher education with the state, except possibly public community colleges."

In the study of statewide coordination of public higher education, several trends can be clearly discerned in table 1 . The first is the obvious trend toward some type of statewide coordinating agency. Second, the number of coordinating boards with regulatory powers has greatly increased, while the number with purely advisory powers has decreased. Third, there has been some movement from coordination through coordinating boards to coordination through consolidated statewide governing boards.

Clearly, academic libraries and librarians must function today within a budgeting and policy framework that is dimensionally broader than the traditional

Vicki L. Gregory is Head, Department of Systems and Operations at Auburn University, Montgomery, Alabama 36193-0401. The doctoral research on which this paper is based was partially funded by the 1985 ACRL Doctoral Dissertation Fellowship. 
TABLE 1

TRENDS IN STATEWIDE COORDINATION, 1940-85

\begin{tabular}{lrrrrrrr}
\hline \hline $\begin{array}{c}\text { Coordinating } \\
\text { Structure }\end{array}$ & 1940 & 1950 & 1960 & 1970 & 1976 & 1982 & 1985 \\
\hline $\begin{array}{l}\text { None } \\
\text { Voluntary }\end{array}$ & 33 & 28 & 17 & $2^{*}$ & $2^{*}$ & $3+$ & 3 \\
$\begin{array}{c}\text { Advisory } \\
\text { coordinating } \\
\text { board }\end{array}$ & 1 & 3 & 6 & 2 & 0 & 0 & 0 \\
$\begin{array}{c}\text { Regulatory } \\
\text { coordinating } \\
\text { board }\end{array}$ & 1 & 2 & 6 & 14 & 20 & 20 & 21 \\
$\begin{array}{c}\text { Consolidated } \\
\text { governing } \\
\text { board }\end{array}$ & 13 & 14 & 16 & 19 & 19 & 21 & $21 \S$ \\
Total & 48 & 48 & 50 & 50 & 50 & 50 & 50 \\
\hline
\end{tabular}

* Delaware and Vermont have an appointed planning agency only.

Wyoming abolished its coordinating council.

$\ddagger$ Washington replaced its advisory board with one having some regulatory authority.

$\S$ In addition to a governing board, Florida, New Hampshire, Alaska, and Oregon also have a separate statutory coordinating agency.

library/university administration/board of trustees structure. The movement toward consolidated statewide governing boards places each institution's academic library in the position of being not just the library but rather $a$ library within a statewide system. As such, while many of the traditional problems of library funding and programs remain to be faced, new ones must be taken into account. Among them is the library's position as perhaps the most funded and easily shared resource within a statewide system. A chemistry laboratory cannot be moved easily, but a book (or even more so an electronic text) on chemistry can be moved and shared. The potential impact on system and institutional budgeting is obvious, as is the tremendous positive potential for coordinated statewide cooperative programs. These and other implications of heightened statewide-level coordination of academic institutions may not, however, be presently fully realized, either by university administrators or librarians.

\section{STATEMENT OF PURPOSE}

Numerous books and articles have been written on the origins and functions of coordinating agencies, but little on the influence of these agencies on particular programs or activities of the affected institutions, such as the operation of their libraries. ${ }^{3}$ The increasing costs of operation and the declining (in real dollars terms) budgets of many universities and colleges in the 1970 s resulted in the involvement of some state coordinating agencies in both programmatic coordination and the funding of academic libraries on a statewide multi-institutional basis, ostensibly in order to make more efficient use of the state's limited resources. This involvement has received only cursory study. ${ }^{4}$ The purpose of this study was to examine the development over the past twenty years (1965-85) of the relationship between state coordinating agencies and statewide library cooperative programs and the funding of academic libraries in pubic universities of selected states.

\section{METHODOLOGY}

This research project was a qualitative study utilizing the grounded theory approach. Briefly, formulating a grounded theory requires a comparative approach in which data collection, coding, analysis, and theorizing are both simultaneous and progressive. During the course of the study, opinions and facts were gathered to synthesize them into a picture of the relationships among various factors that seem to influence the funding of academic libraries in public institutions and the existence and perceived success of statewide library cooperative programs. 


\section{Sample Selection}

The initial sample involved a survey mailed to all public institutions offering graduate work in the following fifteen states: Alabama, Arkansas, California, Florida, Georgia, Illinois, Louisiana, Massachusetts, Minnesota, North Carolina, Oklahoma, Texas, Virginia, Washington, and Wisconsin. The second phase of the project consisted of a more intensive study, including on-site interviews, in the following states: Alabama, Arkansas, Georgia, Louisiana, North Carolina, and Texas. In addition, Oklahoma and Florida were visited for the purpose of reviewing their current statewide automation/networking projects.

Theoretical factors were considered both in selection of the fifteen states surveyed by mail and the six states studied intensively. The first of these factors was the type of coordinating structure utilized. All three types of coordinating structures currently in existence were present in the selected states during the entire time period studied. Other factors were also considered in the selection of the sample such as the number of both public and independent institutions of higher education in the state; enrollment trends to insure inclusion of states with relatively stable, increasing, and decreasing enrollments; personal income per capita; and tax revenue per capita.

\section{Data Collection}

Three methodologies were used to collect the data: content analysis, survey, and interview. First, basic factual data were gathered on the funding process in each state and the existence of statewide library programs. Second, a mail survey was conducted in fifteen states, utilizing questionnaires sent to library directors, university administrators, and staff members of state coordinating agencies in each state. The information gained from this portion of the project determined issues to be focused upon in the more intensive portion of the study.

The next phase of the project focused on qualitative techniques to build theory. A content analysis of the available publica-
"An attempt was made to evaluate
statewide library/program successes
and failures as judged by interview-
ee's perceptions."

tions of the coordinating agencies concerning academic libraries in each of the six states studied intensively was performed. The purpose of the content analysis was to identify concerns and the solutions to these concerns that have at least been suggested in print. The onsite interviews focused on issues identified in the survey and in the analyzed publications. The interviews also were intended to identify concerns not expressed and possibly could not be expressed in any of the documents. An examination of the factor of individual and institutional leadership was conducted at this stage. An attempt was made to evaluate statewide library/ program successes and failures as judged by interviewee's perceptions in order to suggest relationships among the various situational variables that might influence the perceived success or failure of these programs or policies.

\section{ANALYSIS OF DATA}

Three kinds of data were considered: content analysis data, questionnaire data, and interview data. The discussion here must be of a representative nature only as the full descriptions of the programs and policies of the states where interviews were conducted are necessarily long and detailed. For a more complete discussion, see the dissertation.

\section{Content Analysis}

First, only in the six preselected states where interviews were conducted was a concerted effort made to collect and examine systematically all pertinent documents. Unfortunately, even in these states it was occasionally difficult to obtain access to all the potentially relevant materials, due to limited publication runs of some items for immediate administrative 
usage only and the supposed confidentiality of some of the information. In the other nine states, documents forwarded with survey responses or mentioned by survey respondents in cover letters or by another researcher were examined.

As would be expected, funding was found to be in all states a major, if not the major issue. Beyond funding, however, the issues naturally become somewhat dissimilar in the states studied; nevertheless, several issues, when described in generalized terms, were found to be common to several states. For discussion purposes these other issues were collapsed into two additional categories: (1) networking and resource sharing, and (2) program approval and collection development.

\section{Questionnaires-General Data}

Two hundred library directors and the same number of chief academic officers, constituting the total population of library directors and chief academic officers in universities supporting graduate education in the fifteen states studied, were sent questionnaires. In addition, eighteen staff members of the various coordinating agencies were surveyed, along with two directors of academic library networks funded by a state coordinating agency. The reason for more than fifteen agencies is that in three states with consolidated governing boards, a coordinating council existed in addition to the board and questionnaires were sent to both. (John Millett suggests in his book Conflict in Higher Education that there may be a developing trend toward this type of structure.) ${ }^{6}$ During the interviews it was discovered that one of the agencies, the Georgia Commission on Postsecondary Education, no longer existed, so only one coordinating agency failed to respond in some form or the other. A follow-up mailing was sent to nonrespondents one month after the initial mailing. Some of the responses not deemed usable consisted of letters, some of which contained information utilized in either the content analysis or in the interview analysis.

\section{Interviews-General Data}

Forty-five interviews were conducted in eight states with thirty-nine of these interviews being conducted in the six states studied intensively. Representatives of the three groups surveyed (library directors, chief academic officers, and coordinating agency staff) were interviewed (see table 2). In each of the interviews, issues identified from the survey results and from the content analysis were explored in as much depth as time and the knowledgeability of the interviewee permitted. While an effort was made to ensure that the same basic matters were touched upon in each interview, no attempt was made to circumscribe the discussion, and the particular interests of each interviewee were therefore explored in some depth.

\section{TABLE 2}

\begin{tabular}{|c|c|c|c|}
\hline & Sent & Responses & Usable \\
\hline $\begin{array}{l}\text { Library } \\
\text { directors }\end{array}$ & 200 & $150 \quad(75 \%)$ & $138(69 \%)$ \\
\hline $\begin{array}{l}\text { Chief academic } \\
\text { officers }\end{array}$ & 200 & 141 (70.5\%) & $136(68 \%)$ \\
\hline $\begin{array}{l}\text { Staff coordinating } \\
\text { boards }\end{array}$ & 20 & $(90 \%)$ & $15(75 \%)$ \\
\hline
\end{tabular}

\section{FINDINGS}

First, some of the questionnaire results will be discussed. This discussion will be followed by the major conclusions drawn from all data, i.e., content analysis, survey, and interview.

All segments surveyed were asked to respond to a list of statements using a fivepoint scale: strong agreement, agreement, neutral, disagreement, or strong disagreement. The first of these statements to be discussed is "Academic libraries in recent years have received greater attention from the state coordinating agency." The results can be seen in table 3 .

In the aggregate, the most frequent response was "agreement." When the data were cross-tabulated on the basis of the type of coordinating board, those respondents from states with consolidated governing boards tended to indicate strong 
agreement with the statement; those in states with regulatory coordinating boards divided their responses between strong agreement and agreement, and those in states with advisory coordinating boards showed random responses. When the responses from library directors were cross-tabulated by ARL and non-ARL libraries, the ARI library directors indicated strong agreement with the statement.

All three groups were similarly asked to respond to the following statement: "Library directors have an appropriate degree of influence on policies of coordinating agencies that affect libraries." The results can be seen in table 4 .

The majority of the staff members of the coordinating agencies responding agreed with the statement, while about a third of the library directors and less than half of the chief academic officers agreed. When the library directors' responses were compared-based on whether or not there is an advisory committee of librarians to the coordinating agency (see table 5)-it was discovered that $53 \%$ of those responses from states where no advisory committee exists disagreed with the state- ment, as compared to $21 \%$ of the responses from states where a committee does exist. On the other hand, in states where advisory committees exist, $45 \%$ of the library directors agreed with the statement as compared to $17 \%$ in states where no such committee exists.

Turning to the funding/budgeting process, all three groups surveyed were asked to respond to this statement: "State coordinating agency has a key role in financial support of libraries." Respondents tended to indicate agreement with the statement. Fifty-two percent of the library directors, $65 \%$ of the chief academic officers, and $66 \%$ of the coordinating board staff members responded either in agreement or strong agreement with the statement.

Again, all three groups were asked to respond to the statement that "State coordinating agencies have diverted funds from research libraries." The above statement verbalizes a fear that has appeared in the library literature as at least a possible outcome of library funding influenced by state coordinating agencies. The responses do not indicate a general percep-

TABLE 3

ACADEMIC LIBRARIES IN RECENT YEARS HAVE RECEIVED GREATER ATTENTION FROM THE STATE COORDINATING AGENCY

\begin{tabular}{lccc}
\hline \hline & $\begin{array}{c}\text { Library } \\
\text { Directors }\end{array}$ & $\begin{array}{c}\text { Chief } \\
\text { Academic } \\
\text { Officers }\end{array}$ & $\begin{array}{c}\text { Coordinating } \\
\text { Board Staff }\end{array}$ \\
\hline Strong agreement & $32(24 \%)$ & $23(17 \%)$ & $5(33.33 \%)$ \\
Agreement & $50(38 \%)$ & $55(40 \%)$ & $5(33.33 \%)$ \\
Neutral & $28(21 \%)$ & $34(25 \%)$ & $5(33.33 \%)$ \\
Disagreement & $19(14 \%)$ & $20(15 \%)$ & 0 \\
Strong disagreement & $4(3 \%)$ & $\frac{4}{136}(3 \%)$ & $\underline{15}$ \\
$\quad$ Total responses & 133 & & $\frac{15}{15}$ \\
\hline
\end{tabular}

TABLE 4

LIBRARY DIRECTORS HAVE AN APPROPRIATE DEGREE OF INFLUENCE ON POLICIES OF COORDINATING AGENCIES THAT AFFECT LIBRARIES

\begin{tabular}{|c|c|c|c|}
\hline & $\begin{array}{c}\text { Library } \\
\text { Directors }\end{array}$ & $\begin{array}{c}\text { Chief } \\
\text { Academic } \\
\text { Officers }\end{array}$ & $\begin{array}{l}\text { Coordinating } \\
\text { Agency Staff }\end{array}$ \\
\hline $\begin{array}{l}\text { Strong agreement } \\
\text { Agreement } \\
\text { Neutral } \\
\text { Disagreement } \\
\text { Strong disagreement }\end{array}$ & $\begin{array}{l}11(8 \%) \\
47(35 \%) \\
25(19 \%) \\
40(30 \%) \\
10(8 \%) \\
\end{array}$ & $\begin{array}{rr}11 & (8 \%) \\
57 & (43 \%) \\
31 & (23 \%) \\
30 & (22 \%) \\
5 & (4 \%) \\
\end{array}$ & $\begin{array}{lr}2 & (13 \%) \\
9 & (60 \%) \\
1 & (7 \%) \\
3 & (20 \%) \\
0 & \end{array}$ \\
\hline Total responses & $\overline{133}$ & $\overline{134}$ & $\overline{15}$ \\
\hline
\end{tabular}


TABLE 5

DIRECTORS' ANSWERS TO THE QUESTION CONCERNING THEIR INFLUENCE ON POLICIES OF COORDINATING AGENCIES WHEN COMPARED TO EXISTENCE OR NOT OF ADVISORY COMMITTEE

\begin{tabular}{lcc}
\hline \hline & $\begin{array}{c}\text { Advisory } \\
\text { Committee }\end{array}$ & $\begin{array}{c}\text { No Advisory } \\
\text { Committee }\end{array}$ \\
\hline Strong agreement & $11(13 \%)$ & 0 \\
Agreement & $39(45 \%)$ & $8(17 \%)$ \\
Neutral & $12(14 \%)$ & $10(21 \%)$ \\
Disagreement & $18(21 \%)$ & $25(53 \%)$ \\
Strong disagreement & 6 & $\underline{4}(9 \%)$ \\
$\quad$ Total responses & $\overline{86}$ & $\underline{47}$ \\
\hline
\end{tabular}

tion that any such diversion is taking place at least in most of the states studied. Sixtyone percent of the library directors, $61 \%$ of the chief academic officers, and $80 \%$ of the staff members of the coordinating boards responded either in disagreement or strong disagreement. No staff member of a coordinating board agreed with the statement, but three did mark the neutral box. Since most of the responses in agreement with the statement came from two states, such diversion as suggested by the statement may in fact be occuring in a few cases. When the library director and chief academic officer responses were compared on the basis of ARL and non-ARL libraries, the responses did not vary for the overall pattern.

Turning to library cooperative programs, all three groups were asked to respond to the statement "State coordinating agencies have encouraged library cooperation." Most respondents indicated agreement with the statement with only a very small percentage indicating either disagreement or strong disagreement. The staff member of a coordinating agency who disagreed with the statement indicated in the comments section of the questionnaire that while his particular agency encouraged library cooperation, he did not believe other coordinating agencies were as concerned about academic library cooperation.

When asked to respond to the statement that the "Advantages of statewide coordination of library cooperative programs outweigh the disadvantages," the major- ity of all three groups indicated either strong agreement or agreement.

A list of cooperative programs was provided to library directors as part of their questionnaire, and they were asked, if these types of programs existed in their state, whether in their opinion such programs have been successful, moderately successful, generally unsuccessful, or very successful. The results can be seen in table 6.

\section{MAJOR CONCLUSIONS}

Based on the survey and interview data, several factors were identified that coexist with successful interaction between academic libraries and state coordinating agencies as evidenced by special funding programs for libraries and successful library cooperative programs. While the type of coordinating agency was not found to be in itself determinative, a change in the type of agency, whatever the change, was seem to result in an increased level of activity between the academic libraries and the coordinating agency. In some states, of course, after a brief flurry of such activity, progress did not continue, but in others sustained activity was exhibited. The effort itself to bring about the change in the coordinating agency no doubt occurred because of dissatisfaction with the older agency, a dissatisfaction that may have itself been engendered because of an unwillingness on the part of institutions to work together 
TABLE 6

LIBRARY COOPERATIVE PROGRAMS AND THEIR PERCEIVED SUCCESS

\begin{tabular}{|c|c|c|c|c|c|c|}
\hline Program & Successful & $\begin{array}{l}\text { Moderately } \\
\text { Successful }\end{array}$ & $\begin{array}{l}\text { Percentage of } \\
\text { Generally } \\
\text { Unsuccessful }\end{array}$ & $\begin{array}{l}\text { pondents } \\
\text { Very } \\
\text { Unsuccessful }\end{array}$ & $\begin{array}{c}\text { Not } \\
\text { Applicable }\end{array}$ & $\begin{array}{c}\text { No } \\
\text { Answer }\end{array}$ \\
\hline $\begin{array}{l}\text { Director borrowing } \\
\text { Statewide ILL } \\
\text { Union list serials } \\
\text { Union list books } \\
\text { Network }\end{array}$ & $\begin{array}{l}43 \\
61 \\
22 \\
16 \\
22\end{array}$ & $\begin{array}{l}25 \\
22 \\
33 \\
14 \\
24\end{array}$ & $\begin{array}{r}4 \\
3 \\
13 \\
7\end{array}$ & $\begin{array}{l}1 \\
0 \\
5 \\
4\end{array}$ & $\begin{array}{l}22 \\
11 \\
22 \\
52\end{array}$ & $\begin{array}{l}5 \\
3 \\
5 \\
5\end{array}$ \\
\hline $\begin{array}{l}\text { Depository for } \\
\text { little-used materials } \\
\text { Statewide book bid } \\
\text { Statewide periodical }\end{array}$ & $\begin{array}{l}4 \\
4\end{array}$ & $\begin{array}{l}5 \\
9\end{array}$ & $\begin{array}{l}7 \\
4\end{array}$ & $\begin{array}{r}12 \\
4\end{array}$ & $\begin{array}{l}67 \\
75\end{array}$ & $\begin{array}{l}4 \\
4\end{array}$ \\
\hline $\begin{array}{l}\text { bid } \\
\text { Divided responsibilities } \\
\text { collection }\end{array}$ & 2 & 4 & 5 & 5 & 78 & 4 \\
\hline $\begin{array}{l}\text { development } \\
\text { Online circulation } \\
\text { link among public } \\
\text { academic libraries }\end{array}$ & 10 & 6 & 4 & 7 & 78 & 14 \\
\hline $\begin{array}{l}\text { State contract for } \\
\text { online circulation } \\
\text { system } \\
\text { State contract for }\end{array}$ & 9 & 7 & 1 & 3 & 74 & 5 \\
\hline $\begin{array}{l}\text { State contract for } \\
\text { database service } \\
\text { State contract for } \\
\text { library security } \\
\text { system }\end{array}$ & 8 & 8 & 1 & 4 & 72 & 7 \\
\hline
\end{tabular}

under the old system. The new or strengthened agency may have had a legislative mandate to make the institutions work together.

A second important factor was found to be the presence of a permanent advisory committee of librarians attached to or reporting to the coordinating agency. From the survey data, which covered fifteen states, eleven states have such a committee and four do not. Three out of the four that do not have such a committee are states with an advisory coordinating council; only Minnesota had this type of committee. Only one state, Louisiana, which has a regulatory coordinating council, and no states that have a consolidated governing board, lacked an advisory committee of librarians. In states such as Arkansas and Louisiana where no such group exists on a permanent basis, it is evidently difficult to keep library concerns before the coordinating agency, and it is particularly difficult for strong leadership to emerge to present those concerns to the coordinating agency.

In specific, the more homogeneous the makeup of the committee in terms of the type of institutions the more effective it would appear to be. For example, a separate committee for community and junior colleges and a separate committee for university libraries, etc., tends to maximize common interests. In North Carolina, the library directors of the University System, which is composed of sixteen institutions, were able to obtain increased funding in order to upgrade their collections substantially during the 1970 s, and more recently received a special legislative appropriation for automation. In Florida, the nine university libraries are participating in a statewide automation project that has been funded separately from the normal institutional appropriations. On the other hand, in states such as Georgia, where the advisory committee contains representatives from the smallest junior colleges all the way up to those of ARL institutions, it has proven to be very difficult to achieve the kind of nearly unanimous agreement on a proposed project that is usually required to get the attention of a coordinating agency. 
Third, it appears that in order to optimize the chances of success for a statewide library program requiring additional state appropriations, the early presence of an influential person in higher education in the planning states can lend more weight to the appeal for financial support and cooperation from all parties involved. In Alabama, a university president was chair of the committee that brought the Network of Alabama Academic Libraries into being, and in North Carolina the library directors have benefited from the active support of a associate vice president of the University of North Carolina System, whose influence appears to have helped libraries stay high on the system's priority list for funding, both as to continuing programs and as to new project money. Similar examples exist in Oklahoma and Florida.

A fourth factor found to be important is the existence of a person, preferably someone with a library background, on the staff of the coordinating agency with the academic libraries as all or a large part of their permanent responsibilities. In states where library cooperative programs are being implemented with the assistance of the state coordinating agency such a position almost invariably exists, although it is not always filled with a librarian.

The presence of these four factors appear to create the optimum environment for successful interaction between the academic libraries and the state coordinating agency in terms of both cooperative programs and library funding.

\section{"There did not appear to be any rela- tionship between the relative eco- nomic condition of a state and the ex- istence of a close working relation- ship between the academic libraries and the state coordinating agency."}

Perhaps surprisingly, there did not appear to be any relationship between the relative economic condition of a state and the existence of a close working relationship between the academic libraries and the state coordinating agency, at least as evidenced by the existence of successful special funding programs or successful statewide cooperative library programs.

Other factors that were examined but concluded to be unimportant were the relative rising or declining enrollment counts and the balance of private to public institutions of higher education in the state.

When comparing the answers to the survey questions concerning the importance of persons or entities outside the particular institutions, the library directors' responses varied considerably from those of the chief academic officers and the staff members of the coordinating agencies. Such a difference may reflect a naiveté on the part of too many library directors as to the various outside influences on their budgets and a simple acceptance of whatever the university is willing to dole out to them rather than an active participation in obtaining maximum funding for their library. Also, in the interview process it was apparent that in many cases new library directors had not concerned themselves with the history of library funding and cooperative programs in their state, but rather had started fresh, so to speak. This statement is not meant to imply that a full-scale knowledge of the appropriate history is required of all directors, but some understanding of those earlier efforts could lead to the implementation of more successful programs in the future.

The importance of the statewide agency may not be as readily apparent to the academic libraries "inside the system" as it may appear to the outside observer. The indubitable policies surrounding many state coordinating agencies doubtless have some impact here-such policies may seem no different from those traditionally practiced by state legislators. In any event, university administrators seem clearly more likely to recognize the difference than do library directors, and presumably they can act upon their perceptions. 


\section{Theory}

The theory advanced is that effective relations between state coordinating agencies of higher education and academic libraries of public institutions and the perceived success of the activities that are undertaken require the existence of an interfacing mechanism to make academic librarians a part of the coordinating process. The theory is grounded in the observations drawn from this study that advisory committees of librarians constituted in a manner to facilitate communication between institutions and coordinating agencies exist in those states in which generally favorable perceptions exist respecting library-related programs or functions of coordinating agencies. It is not submitted that the mere existence of such an interfacing mechanism is itself sufficient to produce invariably effective relations between state coordinating agencies and academic libraries.

\section{Implications for \\ Academic Libraries in \\ Public Institutions}

In many of the states studied a sizable number of academic library directors do not appear to perceive the importance or potential importance of the state coordinating agency to their library. Often the institution, meaning the university as a whole, is perceived to block out or filter any effects from a state agency. However, both from a logical standpoint and based on discussions with chief academic officers and with the staff members of various coordinating agencies this is clearly not always the case in reality. In many cases library administrators need to be more proactive in putting forth the needs of their libraries and not just reactive to coordinating agency proposals or policies deemed to be harmful or incorrect. For example, when funding formulas are used at the agency level, library directors should insure that they are aware of all the factors on which the formula calculations are based, but this research has shown that far less than all of them actually do.

If they are not aware of what the formulas are based upon and how the cost fac-

\begin{abstract}
"In many cases library administrators need to be more proactive in putting forth the needs of their libraries and not just reactive to coordinating agency proposals or policies deemed to be harmful or incorrect."
\end{abstract}

tors that drive the formulas are determined, how can they individually or collectively hope to know whether the formulas are "just," or know whether and how to make a case for a fairer or more accurate formula? Also, since it would appear that there has become an increasingly faster turnover rate in library administrators, new library directors need to make themselves more aware of the history of library funding and cooperative programs in their state and their relationship with the state coordinating agency. Except for those few who spend their careers in virtually one place, it is difficult for a director, who may spend only a couple of years in one state and then move on to another, to have any sense of historical perspective about what may be seen as local issues; but it is also obviously important that the historical perspective be recognized if the libraries in a state are to build upon prior actions, plans, and successes.

\section{Limitations of the Study}

1. The theory generated from the study needs to be tested. As none of the sampling was random, one cannot know whether the patterns identified necessarily hold true throughout the nation.

2. Due to financial and time limitations, the states studied intensively were mostly in the southeastern United Stated.

3. The economies of three states where interviews were conducted, Louisiana, Texas, and Oklahoma, were being seriously affected by the significant decline in world oil prices taking place at the time and the concomitant contraction of the domestic oil industry. In those states the institutions were in the middle or at the be- 
ginning of a major funding crisis that was not anticipated when the study was planned, and its effect on the study results cannot be accurately measured.

\section{REFERENCES AND NOTES}

1. During the fifties and sixties there existed a few voluntary boards formed by the initiative of institutions rather than by the initiative of state government. These boards were generally formed to try to avoid the creation of such an agency by the state. By the 1970s these voluntary boards had been replaced by state agencies.

2. Robert O. Berdahl, Evaluating Statewide Boards (San Francisco, Calif.: Jossey-Bass, 1975), p.2.

3. Ibid., p.3; Kenneth P. Mortimer and T. R. McConnell, Sharing Authority Effectively: Participation, Interaction, and Discretion (San Francisco, Calif.: Jossey-Bass, 1978), p.221; 1982 data from The Control of the Campus (Washington, D.C.: Carnegie Foundation for the Advancement of Teaching, 1982), p.40-41; 1985 data from State Postsecondary Education Structures Handbook 1986 (Denver, Colo.: Education Commission of the States, 1986), p.2-4.

4. The one major study is a descriptive one: Isaac T. Littleton, State Systems of Higher Education and Libraries: A Report for the Council on Library Resources (Washington, D.C.: Council on Library Resources, 1977).

5. Vicki L. Gregory, "State Coordination of Higher Education and Academic Libraries," (Ph.D. diss., Rutgers, 1987).

6. John D. Millett, Conflict in Higher Education: State Government Coordination Versus Institutional Independence (San Francisco, Calif.: Jossey-Bass, 1984). p.241-45. 